\title{
PENGARUH PEMBERIAN MAKANAN JAJANAN, PENDIDIKAN GIZI, DAN SUPLEMENTASI BESI TERHADAP STATUS GIZI, PENGETAHUAN GIZI, DAN STATUS ANEMIA PADA SISWA SEKOLAH DASAR
}

\author{
(The Effect of Snack Feeding, Nutrition Education, and Iron Suplementation to Nutritional Status, Nu- \\ trition Knowledge, and Anemia Status in Elementary School Students) \\ Adhitya Aji Candra ${ }^{*}$, Budi Setiawan¹, dan M. Rizal M. Damanik ${ }^{1}$ \\ 'Departemen Gizi Masyarakat, Fakultas Ekologi Manusia (FEMA), Institut Pertanian Bogor, Bogor 16680
}

\begin{abstract}
The objective of this research were to analyze the effect of snack feeding, nutrition education, and iron supplementation to nutritional status, nutrition knowledge, and anemia status in elementary school students. The study was conducted in SDN Palasari 02 Kecamatan Cijeruk, Kabupaten Bogor, Jawa Barat. The design of this study was pre-post intervention study. The number of subjects were 81 students. The result showed that snacking did not give significant improvement on nutritional status $(p>0.05)$. Nutrition education was significant in improving nutrition knowledge $(p<0.05)$, while iron supplementation intake gave a significant improvement on anemia status $(p<0.05)$.
\end{abstract}

Keywords: anemia status, nutrition knowledge, nutritional status, snack food

\begin{abstract}
ABSTRAK
Tujuan penelitian ini adalah menganalisis pengaruh pemberian makanan jajanan, pendidikan gizi, dan suplementasi besi terhadap status gizi, pengetahuan gizi, dan status anemia pada siswa sekolah dasar. Penelitian dilaksanakan di SDN Palasari 02 Kecamatan Cijeruk, Kabupaten Bogor, Jawa Barat. Desain penelitian yang digunakan adalah pre-post intervention study dengan menggunakan 81 subjek. Hasil penelitian menunjukkan bahwa pemberian makanan jajanan tidak memberikan pengaruh yang signifikan terhadap status gizi ( $>0.05)$. Pendidikan gizi memberikan pengaruh yang signifikan terhadap pengetahuan gizi $(p<0.05)$, sedangkan pemberian suplemen besi memberikan pengaruh yang signifikan terhadap status anemia $(p<0.05)$.
\end{abstract}

Kata kunci: makanan jajanan, pengetahuan gizi, status anemia, status gizi

"Korespondensi: Departemen Gizi Masyarakat, Fakultas Ekologi Manusia (FEMA), Institut Pertanian Bogor, Bogor 16680. Email: adhityaajicandra@yahoo.co.id 


\section{PENDAHULUAN}

Keberhasilan pembangunan suatu bangsa ditentukan oleh Sumber Daya Manusia (SDM) yang berkualitas. Periode usia sekolah merupakan bagian dari tahapan dalam siklus hidup manusia yang sangat menentukan kualitas SDM. Namun, status gizi, tingkat pengetahuan gizi, dan adanya masalah gizi lainnya merupakan masalah yang terjadi pada anak sekolah dasar. Menurut laporan Riskesdas tahun 2007, prevalensi nasional anak usia sekolah kurus sebesar $13.3 \%$ pada laki-laki dan $10.9 \%$ pada perempuan. Pada sekolah dasar negeri, memiliki pengetahuan gizi dan kesehatan kurang dengan persentase sebesar $86.4 \%$. Prevalensi anemia di Provinsi Jawa Barat pada kelompok usia anak dan remaja yang berusia 5-14 tahun adalah sebesar 18.8\%. Adanya masalah tersebut diperlukan penanganan yang cukup serius. Intervensi perlu dilakukan untuk memperbaiki kualitas SDM pada usia sekolah.

Penanganan yang dapat dilakukan untuk memperbaiki status gizi adalah pemberian makanan jajanan. Selain harga yang murah, menurut Syarifah (2010), kontribusi makanan jajanan terhadap konsumsi sehari siswa sebesar $30 \%$ energi dan $22.3 \%$ protein. Pendidikan gizi merupakan intervensi yang dapat dilakukan untuk memperbaiki pengetahuan gizi. Anak sekolah mudah menerima upaya pendidikan gizi. Suplementasi merupakan salah satu upaya yang dapat dilakukan untuk memperbaiki status anemia. Pemberian suplementasi merupakan pendekatan dasar pertama untuk pencegahan anemia defisiensi besi.

Untuk menciptakan SDM yang berkualitas, dibutuhkan peran serta masyarakat dan pihak swasta. Keterlibatan pihak swasta, saat ini sangat dimungkinkan mengingat pihat swasta juga memiliki program yang disebut dengan CSR (Corporate Social Responsibility). Departemen Gizi Masyarakat IPB bekerja sama dengan PT Ajinomoto Indonesia meluncurkan program kantin sehat. Program ini bertujuan menyediakan jajanan bergizi dan sehat bagi anak sekolah.

Tujuan penelitian ini adalah untuk mempelajari pengaruh pemberian makanan jajanan, pendidikan gizi, dan suplementasi besi terhadap status gizi, pengetahuan gizi, dan status anemia pada siswa sekolah dasar.

\section{METODE}

\section{Desain, Tempat, dan Waktu}

Desain penelitian ini adalah pre-post intervention study. Penelitian ini merupakan bagian dari penelitian payung Ajinomoto IPB Nutrition Program yang berjudul "Peningkatan Status Gizi dan Kesehatan Anak Sekolah melalui Peningkatan Mutu dan Keamanan Makanan Jajanan Kantin". Penelitian ini dilakukan di SDN Palasari 02 Kecamatan Cijeruk, Kabupaten Bogor, Jawa Barat. Penelitian ini dilaksanakan pada bulan September 2012 sampai Pebruari 2013.

\section{Jumlah dan Cara Penarikan Subjek}

Jumlah subjek diperoleh dengan hasil 59 subjek (Lemeshow \& David 1997). Peneliti menggunakan estimasi drop out sebesar $10 \%$, sehingga diperoleh jumlah subjek minimal sebesar 65 orang. Pada awal penelitian jumlah seluruh subjek sebanyak 104, dengan jumlah masing-masing kelas 4, 5, dan 6 sebesar 41 subjek, 36 subjek, dan 27 subjek. Subjek yang memenuhi kriteria inklusi ((1) merupakan siswa kelas 4, 5, dan 6 SDN Palasari 02, (2) terdiri dari laki-laki dan perempuan, (3) bersedia mengisi kuesioner, (4) bersedia diambil darah untuk penentuan kadar hemoglobin dalam darah) resmi menjadi subjek dalam penelitian ini, yaitu sebesar 100 subjek. Sebelum diberikan intervensi atau perlakuan, dilakukan pengambilan data baseline. Perlakuan diberikan setiap hari kepada subjek selama tiga bulan. Kemudian setelah tiga bulan dilakukan pengambilan data endline. Dalam proses pemberian intervensi dan pengambilan data endline terjadi drop out sehingga pada akhirnya diperoleh subjek sebesar 81 .

\section{Jenis dan Cara Pengumpulan Data}

Data yang dikumpulkan terdiri dari data primer dan sekunder. Data primer yang digunakan adalah baseline dan endline data pada penelitian payung Ajinomoto IPB Nutrition Program. Data primer yang dikumpulkan yaitu karakteristik siswa (jenis kelamin, umur, uang saku, status gizi, pengetahuan gizi, dan status anemia), pola konsumsi makanan sumber zat besi, kandungan gizi dan daya terima makanan jajanan, serta kadar hemoglobin dalam darah. Data sekunder yang dikumpulkan yaitu keadaan umum SDN Palasari 02.

Data karakteristik siswa diperoleh melalui wawancara menggunakan kuesioner. Data status gizi menggunakan data berat badan dan tinggi badan yang diukur melalui penimbangan dan pengukuran. Data pola konsumsi makanan sumber zat besi diperoleh melalui wawancara dengan menggunakan Food Frequency Questionnaires (FFQ) semi kuantitatif. Data kandungan gizi makanan jajanan didapat berdasarkan perhitungan makanan jajanan yang dihasilkan dari bahan utama maupun tambahan. Data daya terima makanan jajanan diperoleh dengan formulir uji penerimaan. Status gizi diperoleh berdasarkan IMT/U. Data pengetahuan gizi subjek diperoleh dengan menilai jawaban yang diberikan subjek terhadap 20 pertanyaan meliputi pengetahuan tentang zat-zat gizi secara umum, fungsi zat gizi, akibat defisiensi dan kelebihan zat gizi dan perilaku hidup sehat. Data kadar hemoglobin subjek 
diperoleh dengan cara pengambilan darah untuk kemudian dianalisis kadar hemoglobin, yang dilakukan oleh tenaga puskesmas menggunakan instructtion manual automatic electric hemoglobin meter ( $\mathrm{Hb}$ meter).

Intervensi diberikan selama tiga bulan. Sebelum diberikan intervensi, dilakukan pengambilan data status gizi, pengetahuan gizi, dan pengambilan darah yang merupakan data baseline. Selanjutnya subjek diberi intervensi, yakni pemberian makanan jajanan, pendidikan gizi, dan suplementasi zat besi. Suplementasi zat besi diberikan kepada subjek dua minggu sebelum pengambilan data endline, sebelumnya diberikan obat cacing untuk mengurangi gangguan absorpsi. Setelah tiga bulan intervensi, dilakukan pengambilan data endline.

\section{Pengolahan dan Analisis Data}

Data yang diperoleh dianalisis secara deskriptif dan statistik menggunakan program Microsoft Excel dan SPSS 16 for Windows. Untuk mengetahui perubahan status gizi, pengetahuan gizi, dan status anemia sebelum dan setelah intervensi digunakan uji statistik paired t test.

\section{HASIL DAN PEMBAHASAN}

\section{Karakteristik Subjek}

Jenis kelamin. Subjek dalam penelitian ini adalah anak usia sekolah yang terdiri dari siswa kelas 4, 5, dan 6 dengan proporsi berbeda pada setiap kelas. Jumlah subjek dengan jenis kelamin laki-laki sebanyak 37 siswa atau $45.68 \%$ dari total subjek keseluruhan. Subjek dengan jenis kelamin perempuan berjumlah 44 siswa atau $54.32 \%$ dari total subjek keseluruhan.

Usia. Kisaran usia subjek yaitu 9-13 tahun, dengan rata-rata usia yaitu 11 tahun. Sebagian besar subjek berada pada usia 12 tahun dengan persentase sebesar $37.04 \%$. Hanya sebesar $6.17 \%$ dari seluruh subjek berusia 9 tahun. Sebesar $29.63 \%$ berada pada usia 10 tahun. Persentase terendah atau paling kecil berada pada usia 9 dan 13 tahun, yaitu 6.17\%, dan sebanyak 20.99\% subjek berusia 11 tahun.

Uang saku. Berdasarkan sebaran uang saku subjek, maka uang saku (Rp/minggu) dalam penelitian ini dibagi menjadi tiga kategori, yaitu rendah $(\leq 3000)$, sedang $(3001-5000)$, dan tinggi $(>5000)$. Sebagian besar uang saku subjek berada pada tingkat rendah atau rentang $\leq 3000$ dengan persentase $74.07 \%$ sebanyak 60 subjek. Berdasarkan hasil penelitian Syafitri et al. (2009), lebih dari separuh siswa mengalokasikan uang sakunya untuk keperluan membeli makanan jajanan.

\section{Status Gizi}

Status gizi subjek ditentukan dengan menggunakan indikator indeks masa tubuh berdasarkan usia (IMT/U), indikator ini digunakan pada anak usia 5 tahun hingga 19 tahun. Tabel 1 menunjukkan bahwa $80.25 \%$ subjek berstatus gizi normal. Kisaran z-score siswa SDN Palasari 02 yaitu -4.6-2.3. Kategori status gizi siswa SDN Palasari 02 secara berurutan yaitu $2.47 \%$ kategori status gizi sangat kurus, $8.64 \%$ berstatus gizi kurus, $7.41 \%$ status gizi overweight, dan $1.23 \%$ status gizi obese. Rata-rata $z$-score perempuan sebesar -0.70 dan laki-laki sebesar -0.48.

Hasil uji beda menunjukkan bahwa tidak ada berbedaan yang signifikan antara status gizi perempuan dengan laki-laki dan usia subjek dengan kelompok status gizi ( $p>0.05)$. Hasil penelitian Kustiyah et al. (2006) menyatakan kecenderungan bahwa laki-laki memiliki peluang lebih besar untuk mengalami kurang gizi (underweight) dibandingkan perempuan.

\section{Pengetahuan Gizi}

Pengetahuan gizi subjek berada pada ketiga kategori, yaitu kurang $(85.19 \%)$, sedang $(13.58 \%)$, dan baik (1.23\%) (Tabel 2). Hasil uji beda menunjukkan tidak ada perbedaan yang signifikan antara pengetahuan gizi perempuan dan laki-laki $(p>0.05)$,

Tabel 1. Sebaran Jenis Kelamin dan Usia Subjek Berdasarkan Status Gizi

\begin{tabular}{|c|c|c|c|c|c|c|c|c|c|c|c|c|}
\hline \multirow{3}{*}{ Sebaran } & \multicolumn{12}{|c|}{ Status gizi } \\
\hline & \multicolumn{2}{|c|}{ Sangat kurus } & \multicolumn{2}{|c|}{ Kurus } & \multicolumn{2}{|c|}{ Normal } & \multicolumn{2}{|c|}{ Overweight } & \multicolumn{2}{|c|}{ Obese } & \multicolumn{2}{|c|}{ Total } \\
\hline & $\mathrm{n}$ & $\%$ & $n$ & $\%$ & $\mathrm{n}$ & $\%$ & $\mathrm{n}$ & $\%$ & $\mathrm{n}$ & $\%$ & $\mathrm{n}$ & $\%$ \\
\hline \multicolumn{13}{|c|}{ Jenis kelamin: } \\
\hline Perempuan & 0 & 0.00 & 4 & 4.94 & 38 & 46.91 & 2 & 2.47 & 0 & 0.00 & 44 & 54.32 \\
\hline Laki-laki & 2 & 2.47 & 3 & 3.70 & 27 & 33.33 & 4 & 4.94 & 1 & 1.23 & 37 & 45.68 \\
\hline \multicolumn{13}{|l|}{ Usia: } \\
\hline 9 tahun & 0 & 0.00 & 0 & 0.00 & 5 & 6.17 & 0 & 0.00 & 0 & 0.00 & 5 & 6.17 \\
\hline 10 tahun & 0 & 0.00 & 3 & 3.70 & 20 & 24.69 & 1 & 1.23 & 0 & 0.00 & 24 & 29.63 \\
\hline 11 tahun & 0 & 0.00 & 2 & 2.47 & 14 & 17.28 & 1 & 1.23 & 0 & 0.00 & 17 & 20.99 \\
\hline 12 tahun & 1 & 1.23 & 2 & 2.47 & 23 & 28.40 & 3 & 3.70 & 1 & 1.23 & 30 & 37.04 \\
\hline 13 tahun & 1 & 1.23 & 0 & 0.00 & 3 & 3.70 & 1 & 1.23 & 0 & 0.00 & 5 & 6.17 \\
\hline
\end{tabular}


namun terdapat perbedaan antara kelas 4, 5, maupun kelas $6(\mathrm{p}<0.05)$.

\section{Status Anemia}

Rata-rata kadar hemoglobin subjek perempuan dan laki-laki sebesar $9.54 \mathrm{~g} / \mathrm{dl}$ dan $9.80 \mathrm{~g} / \mathrm{dl}$. Kadar hemoglobin merupakan indikator status anemia. Anak usia 5-11 tahun, sudah dikatakan anemia jika kadar $\mathrm{Hb}$ dalam darah $<11.5 \mathrm{~g} / \mathrm{dl}$ dan anak usia 12-14 tahun, sudah dikatakan anemia jika kadar $\mathrm{Hb}$ dalam darah <12 g/dl (WHO 2011).

Hasil uji beda menunjukkan tidak ada perbedaan yang signifikan antara status anemia subjek perempuan dengan laki-laki ( $p>0.05)$. Hasil uji beda menunjukkan tidak ada perbedaan yang signifikan usia subjek antara kelompok status gizi ( $p>0.05)$. Hasil ini mendekati dengan hasil penelitian Sinha et al. (2008) di India pada anak usia 6-35 bulan menunjukkan bahwa prevalensi anemia pada penelitian tersebut sangat tinggi yaitu $80.3 \%$, dimana lebih dari seperempat anak termasuk anemia tingkat ringan $(27.7 \%)$, separuh anak termasuk anemia tingkat sedang (51.3\%), dan 1.3\% anak termasuk ke dalam kategori anemia tingkat berat.

\section{Konsumsi Makanan Sumber Zat Besi}

Bahan makanan sumber zat besi yang dikonsumsi subjek dapat dilihat pada Tabel 3. Total konsumsi zat besi dalam makanan sebesar $10.55 \mathrm{mg} /$ hari. Persentase konsumsi zat besi terhadap kecu-

Tabel 2. Sebaran Jenis Kelamin dan Kelas Subjek Berdasarkan Pengetahuan Gizi

\begin{tabular}{lcccccccc}
\hline & \multicolumn{9}{c}{ Pengetahuan gizi } \\
\cline { 2 - 10 } & \multicolumn{2}{c}{ Sebaik } & \multicolumn{2}{c}{ Sedang } & \multicolumn{2}{c}{ Kurang } & \multicolumn{2}{c}{ Total } \\
\cline { 2 - 10 } & $\mathrm{n}$ & $\%$ & $\mathrm{n}$ & $\%$ & $\mathrm{n}$ & $\%$ & $\mathrm{n}$ & $\%$ \\
\hline Jenis kelamin: & & & & & & & & \\
Perempuan & 0 & 0.00 & 5 & 6.17 & 39 & 48.15 & 44 & 54.32 \\
Laki-laki & 1 & 1.23 & 6 & 7.41 & 30 & 37.04 & 37 & 45.68 \\
\hline Kelas: & & & & & & & & \\
Kelas 4 & 0 & 0.00 & 2 & 2.47 & 28 & 34.57 & 30 & 37.04 \\
Kelas 5 & 0 & 0.00 & 1 & 1.23 & 28 & 34.57 & 29 & 35.80 \\
Kelas 6 & 1 & 1.23 & 8 & 9.88 & 13 & 16.05 & 22 & 27.16 \\
\hline
\end{tabular}

Tabel 3. Rata-rata Konsumsi dan Sumbangan Zat Besi

\begin{tabular}{|c|c|c|c|c|c|}
\hline Bahan Pangan & $\begin{array}{c}\text { Rata-rata } \\
\text { (Frekuensi/bulan) }\end{array}$ & $\begin{array}{l}\text { Konsumsi } \\
\text { g/hari }\end{array}$ & $\begin{array}{l}\text { Asupan Fe } \\
\text { (mg) }\end{array}$ & Nilai Absorpsi & $\begin{array}{l}\text { Asupan Fe } \\
\text { (mg) }\end{array}$ \\
\hline Kacang ijo & 22 & 6 & 0.37 & 0.05 & 0.02 \\
\hline Kacang kedelai & 36 & 3 & 0.19 & 0.05 & 0.01 \\
\hline Kacang merah & 5 & 1 & 0.06 & 0.05 & 0.00 \\
\hline Tempe & 59 & 33 & 3.30 & 0.05 & 0.16 \\
\hline Daging sapi & 8 & 2 & 0.08 & 0.13 & 0.01 \\
\hline Hati sapi & 2 & 1 & 0.08 & 0.13 & 0.01 \\
\hline Telur ayam (kuning) & 49 & 9 & 0.66 & 0.13 & 0.08 \\
\hline Telur asin & 5 & 3 & 0.21 & 0.13 & 0.03 \\
\hline Ikan mas & 12 & 7 & 0.71 & 0.13 & 0.09 \\
\hline Ikan mujair & 6 & 2 & 0.15 & 0.13 & 0.02 \\
\hline Rebon & 7 & 1 & 0.12 & 0.13 & 0.02 \\
\hline Udang & 6 & 1 & 0.07 & 0.13 & 0.01 \\
\hline Bayam & 27 & 13 & 0.77 & 0.05 & 0.04 \\
\hline Daun melinjo & 7 & 2 & 0.09 & 0.05 & 0.00 \\
\hline Pir & 14 & 30 & 1.88 & 0.05 & 0.09 \\
\hline Madu & 5 & 1 & 0.12 & 0.13 & 0.01 \\
\hline Bakwan & 35 & 23 & 1.69 & 0.05 & 0.08 \\
\hline Total & & & 10.55 & & 0.69 \\
\hline \multicolumn{3}{|c|}{ Rata-rata kecukupan per anak per hari } & 16.73 & & 0.89 \\
\hline \multicolumn{3}{|c|}{ \% Terhadap kecukupan } & 64.04 & & 77.72 \\
\hline
\end{tabular}


kupan zat besi sebesar $64.04 \%$. Tempe merupakan makanan yang menyumbangkan zat besi terbesar, yaitu $3.30 \mathrm{mg}$ dalam sehari, sedangkan paling rendah menyumbangkan zat besi adalah kacang merah, daging sapi, hati sapi, ikan mujair, rebon udang, daun melinjo, dan madu sebesar $0.10 \mathrm{mg}$.

Rata-rata pangan yang sering dikonsumsi dan makanan paling banyak dikonsumsi dalam satu hari oleh subjek adalah tempe sebesar 59 kali dalam sebulan dan $33 \mathrm{~g} /$ hari. Makanan yang terbuat dari kacang kedelai ini merupakan makanan yang mudah didapat, ditambah dengan harga yang relatif murah. Makanan yang paling sedikit dikonsumsi subjek sebesar $1 \mathrm{~g} /$ hari yaitu kacang merah, hati sapi, rebon, udang, dan madu.

Persentase total zat besi yang diabsorpsi tubuh sebesar $0.69 \mathrm{mg}$, sedangkan rata-rata kecukupan per anak per hari sebesar $0.89 \mathrm{mg} /$ hari, sehingga nilai persentase terhadap kecukupan zat besi yang diabsorpsi oleh tubuh sebesar $77.72 \%$. Angka ini masih kurang dari kecukupan gizi yang seharusnya. Diduga kekurangan konsumsi zat besi oleh subjek yang mengakibatkan sebagian besar subjek menderita anemia gizi besi. Makanan yang berasal dari pangan hewani jarang diberikan kepada anak-anak di daerah sosioekonomi rendah (Jiang et al. 2009).

\section{Daya Terima dan Kandungan Gizi Makanan Jajan- an}

Rata-rata daya terima subjek terhadap makanan jajanan sangat baik yaitu sebesar $95.33 \%$. Persentase daya terima tertinggi subjek adalah terhadap jajanan donat coklat, jelly, martabak mini, nasi putih ayam, nasi uduk daging, roti bakar, dan singkong keramas $(100.00 \%)$. Persentase daya terima terendah adalah terhadap jajanan mie goreng (89.81\%). Daya terima jajanan mie goreng yang rendah disebabkan karena beberapa subjek kurang menyukai jajanan mie goreng.

Pada penelitian ini, selama kurang lebih tiga bulan subjek diberi makanan jajanan. Dalam satu hari diberikan dua makanan jajanan yang berbeda, yaitu makanan manis dan asin. Nilai rata-rata kandungan energi sebesar $269 \mathrm{Kal}$, protein sebesar 5.39 g, vitamin A sebesar 75.65 RE, dan zat besi sebe- sar $0.96 \mathrm{mg}$. Nilai energi tertinggi terdapat pada makanan jajanan mie goreng dan bolu kukus. Nilai protein tertinggi terdapat pada lemper kuning dan putri ayu. Nilai vitamin A tertinggi terdapat pada makanan jajanan nasi kuning dan krupuk. Nilai zat besi tertinggi terdapat pada makanan jajanan nasi goreng dan putri ayu serta lemper kuning dan putri ayu.

\section{Kontribusi Zat Gizi Makanan Jajanan terhadap AKG}

Kontribusi zat gizi makanan jajanan terhadap Angka Kecukupan Gizi (AKG) merupakan rata-rata kontribusi zat gizi semua makanan jajanan yang diberikan kepada subjek terhadap AKG. Energi, protein, vitamin A, dan zat besi adalah zat gizi yang dihitung kontribusinya. Kontribusi zat gizi tertinggi dari makanan jajanan yaitu vitamin A (14.49\%). Kontribusi zat gizi lainnya dari makanan jajanan terhadap AKG subjek antara lain energi sebesar $13.08 \%$, protein sebesar $10.28 \%$, dan zat besi sebesar 6.56\%. Hasil penelitian Yasmin dan Madanijah (2010) menunjukkan bahwa rata-rata kontribusi energi dari konsumsi jajanan siswa SD lebih dari $20 \%$.

\section{Pengaruh Pemberian Makanan Jajanan terhadap Status Gizi \\ Berdasarkan hasil uji statistik paired $t$ test, tidak terdapat perubahan yang signifikan status gizi (IMT/U) antara sebelum dan setelah intervensi pem- berian makanan jajanan selama kurang lebih tiga bulan ( $p>0.05)$, namun pemberian makanan jajanan meningkatkan z-score subjek. Hal ini menunjukkan bahwa intervensi pemberian makanan jajanan dini- lai tidak berpengaruh terhadap status gizi (IMT/U). Distribusi subjek berdasarkan status gizi subjek sebelum dan setelah intervensi secara lebih rinci dapat dilihat pada Gambar 1.}

\section{Pengaruh Pendidikan Gizi terhadap Pengetahuan Gizi}

Rata-rata tingkat pengetahuan gizi subjek sebelum dan setelah intervensi pemberian pendidikan gizi adalah sebesar $47.53 \%$ (kurang) dan $67.59 \%$

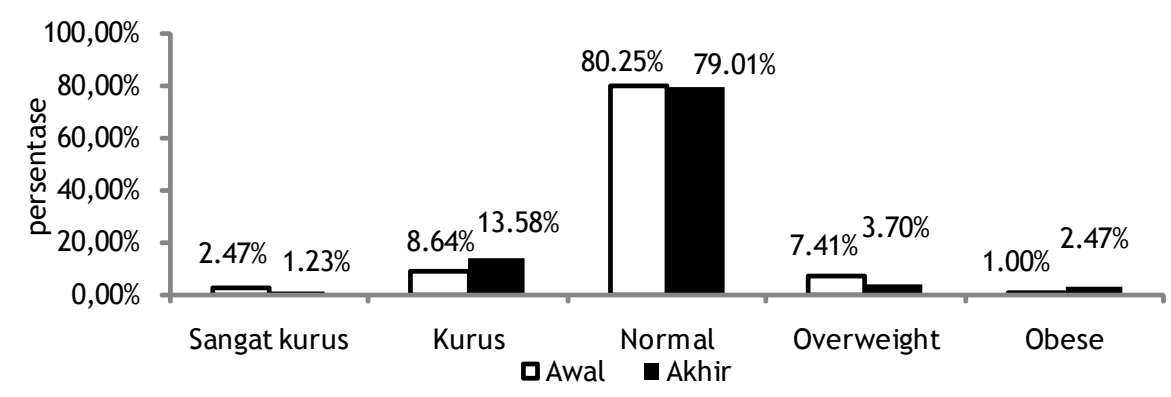

Gambar 1. Perbedaan Status Gizi Sebelum dan Setelah Intervensi Pemberian Makanan Jajanan 
(baik). Peningkatan tingkat pengetahuan gizi subjek sebesar $20.06 \%$. Berdasarkan hasil uji statistik paired $t$ test, terdapat perubahan pengetahuan gizi yang signifikan antara sebelum dan setelah intervensi $(p<0.05)$. Hal ini menunjukkan bahwa intervensi pendidikan gizi yang diberikan selama sebelas hari memberikan pengaruh terhadap pengetahuan gizi subjek. Hasil penelitian Maiburg et al. (2003), menunjukkan bahwa pendidikan gizi meningkatkan pengetahuan gizi aktual subjek.

\section{Pengaruh Suplementasi Besi terhadap Status Ane- mia}

Uji statistik paired t test yang dilakukan pada status anemia subjek menunjukkan adanya perbedaan yang signifikan antara sebelum dan sesudah intervensi $(p<0.05)$. Hal ini menunjukkan bahwa suplementasi zat besi berpengaruh terhadap status anemia subjek. Hasil penelitian ini sejalan dengan hasil penelitian yang dilakukan Silva et al. (2003) pada anak usia 5 sampai 10 tahun di Colombo, Srilanka yang menunjukkan bahwa suplementasi besi secara signifikan memperbaiki status anemia dengan meningkatkan kadar hemoglobin dan serum ferritin. Hasil penelitian lannotti et al. (2006), mengatakan bahwa pemberian suplemen besi memberikan pengaruh terhadap konsentrasi hemoglobin. Gibney (2008) juga mengatakan bahwa suplementasi zat besi merupakan salah satu pencegahan dan pengendalian anemia karena defisiensi zat besi.

\section{KESIMPULAN}

Pemberian makanan jajanan tidak memberikan pengaruh terhadap status gizi subjek, namun terdapat kecenderungan meningkatkan kontribusi asupan zat gizi. Pendidikan gizi memberikan pengaruh terhadap peningkatan pengetahuan gizi subjek, sedangkan suplementasi besi memberikan pengaruh terhadap status anemia, yaitu meningkatkan kadar hemoglobin subjek.

Sebaiknya pemerintah setempat menjadikan pendidikan gizi sebagai mata pelajaran sekolah dasar. Suplementasi besi perlu dilakukan secara rutin kepada siswa sekolah dasar mengingat jumlah penderita anemia di sekolah dasar masih tinggi.

\section{DAFTAR PUSTAKA}

Gibney JG et al. 2008. Gizi Kesehatan Masyarakat. alih bahasa. Andry Hartono; editor edisi baha- sa Indonesia. Palupi Widyastuti. Erita Agustin Hardiyanti. EGC, Jakarta.

lannotti LL, Tielsch JM, Black MM, \& Black RE. 2006. Iron supplementation in early childhood: health benefits and risks. Am J Clin Nutr 84, 1261-76.

Jiang JX et al. 2008. Vitamin A deficiency and child feeding in Beijing and Guizhou, China. World Journal of Pediatrics, 4(1), 20-25.

Kustiyah L, Syarief H, Hardinsyah, Rimbawan, \& Suradijono SH. 2006. Pengaruh Intervensi Makanan Kudapan terhadap Peningkatan kadar Glukosa Darah dan Daya Ingat Anak Sekolah Dasar. Bogor. Media Gizi \& Keluarga, 30(1), 42-57.

Lemeshow S \& David WHJ. 1997. Besar Sampel dalam Penelitian Kesehatan (terjemahan). Gajahmada University Press, Yogyakarta.

Maiburg BHJ, Rethans JE, Schuwirth LWT, Mathus LMH, \& Ree JW. 2003. Controlled trial of effect of computer-based nutrition course on knowledge and practice of general practitioner trainees. Am J Clin Nutr 77, 1019S-24S.

Silva A, Sunethra A, Irangani W, \& Namanjeet A. 2003. Iron supplementation improves iron status and reduces morbidity in children with or without upper respiratory tract infections: a randomized controlled study in Colombo, Sri Lanka. Am J Clin Nutr, 77, 234-41.

Sinha et al. 2008. Epidemiological correlates of nutritional anemia among children (6-35 months) in rural Wardha, Central India. Indian J Med Sci, 62(2), 45-54.

Syarifah. 2010. Kebiasaan Jajan serta Kontribusi Energi dan Zat Gizi Makanan Jajanan terhadap Kecukupan Gizi Siswa Sekolah Dasar [skripsi]. Institut Pertanian Bogor, Bogor.

Syafitri Y, Syarief H, \& Baliwati YF. 2009. Kebiasaan jajan siswa sekolah dasar (studi kasus di SDN Lawanggintung 01 Kota Bogor). Jurnal Gizi dan Pangan, 4(3), 167-175.

[WHO] World Health Organization. 2011. Haemoglobin concentrations for the diagnosis of anaemia and assessment of severity. http: / /www. who.int/vmnis/indicators/haemoglobin.pdf. [4 Feb 2013].

Yasmin G \& Madanijah S. 2010. Perilaku penjaja pangan jajanan anak sekolah terkait gizi dan keamanan pangan di Jakarta dan Sukabumi. Jurnal Gizi dan Pangan, 5(3), 148-157. 